\title{
Thinned stone fruits are a source of polyphenols and antioxidant compounds
}

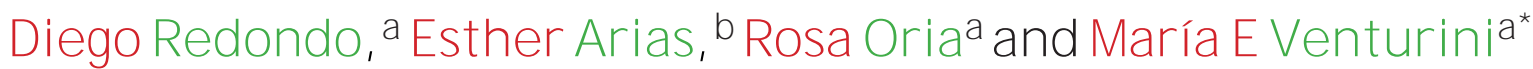

\begin{abstract}
BACKGROUND: Thinned fruitsare agricultural by-products that contain large quantities of interesting compounds due to their early maturity stage. In this work, the phenolic profile and the antioxidant activity of six thinned stone fruits (apricot, cherry, flat peach, peach, plum and nectarine) have been investigated, focussing on proanthocyanidins.
\end{abstract}

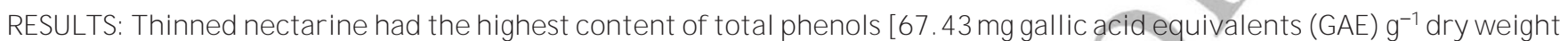
(DW)] and total flavonoids (56.97 $\mathrm{mg} \mathrm{CE} \mathrm{g}^{-1} \mathrm{DW}$ ) as well as the highest antioxidant activity measured by DPPH scavenging (133.30 mg [Trolox equivalents (TE) $\mathrm{g}^{-1} \mathrm{DW}$ ] and FRAP assay (30.42 $\left.\mathrm{mg} \mathrm{TE}^{-1} \mathrm{DW}\right)$. Proanthocyanidins were very abundant in these by-products, and the main phenolic group quantified in cherry $\left(10.54 \mathrm{mgg}^{-1} \mathrm{DW}\right)$, flat peach $\left(33.47 \mathrm{mgg} \mathrm{g}^{-1} \mathrm{DW}\right)$ and nectarine (59.89 $\left.\mathrm{mgg}^{-1} \mathrm{DW}\right)$, while hydroxycinnamic acids predominate in apricot, peach and plum $\left(6.67,22.04 \mathrm{and}^{23.75 \mathrm{mgg}^{-1}}\right.$ DW, respectively). The low, mean degree of polymerisation of proanthocyanidins suggests that their bioavailability could be very high.

CONCLUSIONS: This study shows that thinned stone fruit extracts might be used as antioxidants in foods or as a source of compounds with health-related benefits that can be used in the pharmaceutical, cosmetic and food industries. (c) 2016 Society of Chemical Industry

Keywords: thinned stonefruits; by-products; proanthocyanidins; hydroxycinnamicacids; antioxidant activity

\section{INTRODUCTION}

Industrial processing of fruit and vegetables generates substantial quantities of waste/by-products. In recentyears ithas been amply demonstrated that waste and by-products of fruit and vegetables may be an abundant source of antioxidant polyphenols and other phytochemicals and health-promoting compounds such as terpenoids (carotenoids, essential oils, steroids, etc.), nitrogen and sulfur-containing compounds, etc. ${ }^{1-3}$ The biological activity of these compounds is often related to their antioxidant capacity or their ability to neutralise free radicals that are the origin of many diseases. ${ }^{4}$ Most studies have focused on the use ofindustria by-products, mainly for their application in the pharmaceutical, cosmetic and food industries. Examples are food supplements with high antioxidant contents based on resveratrol from grape pomace or on proanthocyanidins from grape seeds and apple pomace, or body and facial creams based on oils from both peach and apricot seeds. However, there are some agricultural practices, such as pruning or thinning, which also generate substantial quantities of waste whose contents have not yet been studied.

Stone fruit treesgenerally setmorefruitthan can begrownto a marketable size. Therefore, it is necessary to thin somefruits thereby reducing their total number and increasing both theirfinal size and the value of the crop. Thinning also relieves the tree of excessloads, removes the undesirable fruit (doubled, misshapen, scarred, injured, or undersized), and improves the formation of fruit buds for the next season's crop. ${ }^{5}$ However, these small fruits are abandoned in the field generating large quantities of waste or, even worse, being incinerated with the environmental problems which that entails. ${ }^{6}$ Moreover, thinning has both economic and time costs which have been calculated at 3.43-4.11 euro tree ${ }^{-1}$ and $200-300$ h hectare ${ }^{-1}$.

Some studies have shown the influence of the maturity and ripening stage on the phytochemical content in fruits and veg- etables. It has been demonstrated that the phenolic content

is higher in immature fruits at an early stage.$^{6,8-12}$ These com-

pounds decrease during typical fruit ripening whereas levels of colourful anthocyanidins increase. ${ }^{13}$ As thinned fruits have a very early maturity stage, the concentration of phenolic compounds should be very high. They might therefore be considered as a rich source of bioactive compounds which may be extracted for use as supplements in the food, pharmaceutical and cosmetics industries. ${ }^{6}$ The exploitation of thinned fruits for the extraction of compounds of both nutritional and technological importance ${ }^{14}$ may be considered to have considerable economic and environmental benefits.

tos de Origen Vegetal, Instituto Agroalimentario de Aragón-IA2-(Universidad de Zaragoza-CITA), C/Miguel Servet 177, 50013 Zaragoza, Spain. E-mail: ugeventu@unizar.es

a Grupo de Investigación de Alimentos de Origen Vegetal, Instituto Agroalimentario de Aragón-IA2-(Universidad de Zaragoza-CITA), C/Miguel Servet 177, 50013 Zaragoza, Spain

b Parque Científico Tecnológico Aula Dei, Avda. Montañana 930, 50059 Zaragoza, Spain 
Table 1. Physico-chemical parameters of the six thinned stone fruits

\begin{tabular}{|c|c|c|c|c|c|c|c|c|}
\hline Species & Cultivar & $\begin{array}{l}\text { Date of } \\
\text { thinning }\end{array}$ & $\begin{array}{c}\text { Equatorial } \\
\text { diameter (mm) }\end{array}$ & $\begin{array}{c}\text { Polar } \\
\text { diameter } \\
(\mathrm{mm})\end{array}$ & Weight (g) & TSS ( ${ }^{\circ}$ Brix) & $\begin{array}{l}\text { TA (g malic } \\
\text { acid } \mathrm{kg}^{-1} \text { ) }\end{array}$ & $\begin{array}{c}\text { Water } \\
\text { content (\%) }\end{array}$ \\
\hline \multirow{2}{*}{ Apricot } & \multirow{2}{*}{ Pink Cot } & 27 April 2013 & $25.9 \pm 1.0$ & $28.2 \pm 0.9$ & $11.7 \pm 1.7$ & $7.1 \pm 0.3$ & $26.4 \pm 0.8$ & $86.9 \pm 0.9$ \\
\hline & & 29 April 2014 & $26.0 \pm 0.9$ & $27.9 \pm 0.9$ & $10.9 \pm 1.4$ & $7.8 \pm 0.4$ & $27.5 \pm 0.6$ & $87.6 \pm 0.6$ \\
\hline \multirow{2}{*}{ Cherry } & \multirow{2}{*}{$20-09$} & 30 April 2013 & $13.8 \pm 0.8$ & $15.2 \pm 0.8$ & $2.1 \pm 0.2$ & $7.7 \pm 0.3$ & $11.7 \pm 0.6$ & $87.1 \pm 1.6$ \\
\hline & & 29 April 2014 & $13.8 \pm 1.0$ & $14.9 \pm 0.7$ & $1.9 \pm 0.3$ & $7.2 \pm 0.5$ & $13.3 \pm 0.3$ & $86.4 \pm 2.8$ \\
\hline \multirow[t]{2}{*}{ Flat peach } & \multirow[t]{2}{*}{ UFO-3 } & 27 April 2013 & $20.8 \pm 1.2$ & $12.1 \pm 1.1$ & $3.1 \pm 0.6$ & $7.7 \pm 0.3$ & $10.0 \pm 0.2$ & $84.4 \pm 0.9$ \\
\hline & & 28 April 2014 & $19.8 \pm 1.3$ & $11.5 \pm 1.4$ & $3.0 \pm 0.6$ & $7.7 \pm 0.2$ & $9.9 \pm 0.4$ & $83.2 \pm 2.0$ \\
\hline \multirow{2}{*}{ Peach } & \multirow{2}{*}{ Royal Glory } & 29 April 2013 & $21.4 \pm 1.7$ & $28.0 \pm 3.1$ & $3.9 \pm 0.2$ & $8.3 \pm 0.5$ & $8.1 \pm 0.3$ & $86.1 \pm 1.8$ \\
\hline & & 26 April 2014 & $17.4 \pm 1.9$ & $21.1 \pm 2.5$ & $2.8 \pm 0.2$ & $8.1 \pm 0.3$ & $7.8 \pm 0.1$ & $88.4 \pm 2.0$ \\
\hline \multirow{2}{*}{ Plum } & \multirow{2}{*}{ Tolosa } & 07 May 2013 & $19.9 \pm 0.9$ & $24.6 \pm 1.6$ & $5.6 \pm 0.4$ & $7.2 \pm 0.3$ & $19.0 \pm 0.5$ & $88.1 \pm 1.9$ \\
\hline & & 06 May 2014 & $20.0 \pm 1.3$ & $26.4 \pm 1.8$ & $5.1 \pm 0.5$ & $7.7 \pm 0.2$ & $20.8 \pm 0.2$ & $86.2 \pm 1.1$ \\
\hline Nectarine & Laura & 30 April 2013 & $21.1 \pm 1.7$ & $26.8 \pm 2.3$ & $4.4 \pm 1.0$ & $7.5 \pm 0.1$ & $7.4 \pm 0.6$ & $87.1 \pm 1.7$ \\
\hline
\end{tabular}

Phenolic compounds represent a large and important group of abundant secondary metabolites in fruit and vegetables. Polyphenols in plants contribute to several sensory properties and defence mechanisms, and their role in human health protection, related to antioxidant and anti-radical activities, has been repeatedly suggested. ${ }^{15}$ Many classes of polyphenols, classically distinguished as flavonoids and non-flavonoids, are known to be present in many plant tissues. Among these compounds, proanthocyanidins have attracted considerable attention in recent years due to their human health benefits such as reducing cardiovascular diseases, carcinogenesis, neurodegeneration, skin deterioration, diabetic or anti-hyperglycaemic problems, as well as their anti-tyrosinaseactivities. ${ }^{16,17}$ Proanthocyanidins (PAs) are composed of flavan-3-ol monomer units (catechin or epicatechin) linked mainly through $\mathrm{C4}-\mathrm{C} 8$ or $\mathrm{C} 4-\mathrm{C} 6$ interflavan bonds ${ }^{18}$ which form oligomeric proanthocyanidins and polymeric proanthocyanidins. ${ }^{19}$ PAs have properties such as forming stable complexes with metal ions and proteins, and act as good reducing agents. For example, they are able to scavenge reactive oxygen species (ROS), which include radical and non-radical oxygen species such as $\mathrm{O}_{2}{ }^{-}, \mathrm{HO}, \mathrm{H}_{2} \mathrm{O}_{2},{ }^{1} \mathrm{O}_{2}, \mathrm{HOCl}$, as well being able to generate $\mathrm{RO}$ and $\mathrm{ROO}$ free radicals such as those derived from low-density lipoprotein, proteins, and oligonucleic acids (DNA and RNA). ${ }^{20}$

In this study, the potential of six thinned stone fruits (apricot, cherry, flatpeach, peach, plumandnectarine)asanaturalsourceof phenoliccompoundswith highantioxidantactivity wasexamined. Special attention has been focused on proanthocyanidins due to their important health benefits. Tothe best of our knowledge, this is the first report concerning the identification and quantification of bioactive compounds in thinned stone fruits. 53

\section{EXPERIMENTAL}

\section{Fruit samples}

Apricots(Prunusarmeniacacv.PinkCot), cherries(Prunusaviumcv 13S-20-09), flatpeaches (Prunuspersicacv.UFO-3), peaches(Prunus persica cv. Royal Glory), plums (Prunus domestica cv. Tolosa) and nectarines (Prunus persica cv. Laura) were hand-thinned in two seasons ata commercial orchard in Nonaspe (Zaragoza, Spain) located at coordinates $41^{\circ} 13^{\prime} 24.78^{\prime \prime}$ north (latitude) and $0^{\circ}$
4.76" east (longitude) on different days in April or May, but in all cases 42 days after full bloom in 2013 and 48 days after full bloom in 2014 (Table 1).

The experiment involved 20 trees randomly located with the same growth vigour and tree age for each species. For each species, 800 fruits (40 samples per tree) of similar size, colour and an absence of any defect were randomly and manually picked and transferred immediately to the laboratory. One hundred fruits were used for measurement of the fruit size, weight, total soluble solids (TSS), titratable acidity (TA) and water content immediately after picking. Table 1 shows a physico-chemical description of the different fruits and Fig. 1 their visual appearance. Each fruit was weighed on a precision scale to $0.01 \mathrm{~g}$ confidence level and the equatorial and polar diameters were measured using a digital calliper (Mitutoyo, Tokyo, Japan). The soluble solids content (SSC) was determined by crushing the flesh and transferring the intact juice of 25 samples to a digital refractometer (Atago, Tokyo, Japan). Titratable acidity (TA) was measured using an automatic titrator (Crison, Barcelona, Spain). Ten grams of juice of 20 fruits (in triplicate) were diluted with 90 $\mathrm{mL}$ of distilled $\mathrm{H}_{2} \mathrm{O}$ and titrated with

$0.1 \mathrm{molL}^{-1} \mathrm{NaOH}$ solution up to $\mathrm{pH} 8.1$, expressing the results as grams malic acid per kilogram. The water content of 15 whole fruits was determined using a halogen moisture-meter, model HR73 (Mettler Toledo, New York, NY, USA).

The rest of the fruits were used for the determination of phe- nolic and flavonoid contents and antioxidant activities. The sam- ples were frozen in liquid nitrogen, freeze-dried (LyoBeta Telstar, Barcelona, Spain), ground using a pestle and mortar, vacuum packed and maintained in a desiccator at room temperature and darkness untilanalysis.

\section{Preparation of extracts}

The extracts were obtained by mixing $1 \mathrm{~g}$ of freeze-dried sample with $100 \mathrm{~mL}$ of a methanol/water solution (80:20; v:v) and homogenised with an ultraturrax during $30 \mathrm{~s}$. They were then centrifuged at $4000 \mathrm{rpm}$ for $10 \mathrm{~min}$ and at $4^{\circ} \mathrm{C}$ and the supernatant was filtered through $45 \mu$ mnylon filtermembrane. The extraction was donetwiceand both supernatants were mixed and stored at $-18^{\circ} \mathrm{C}$ prior to further use and analysed within a month from 

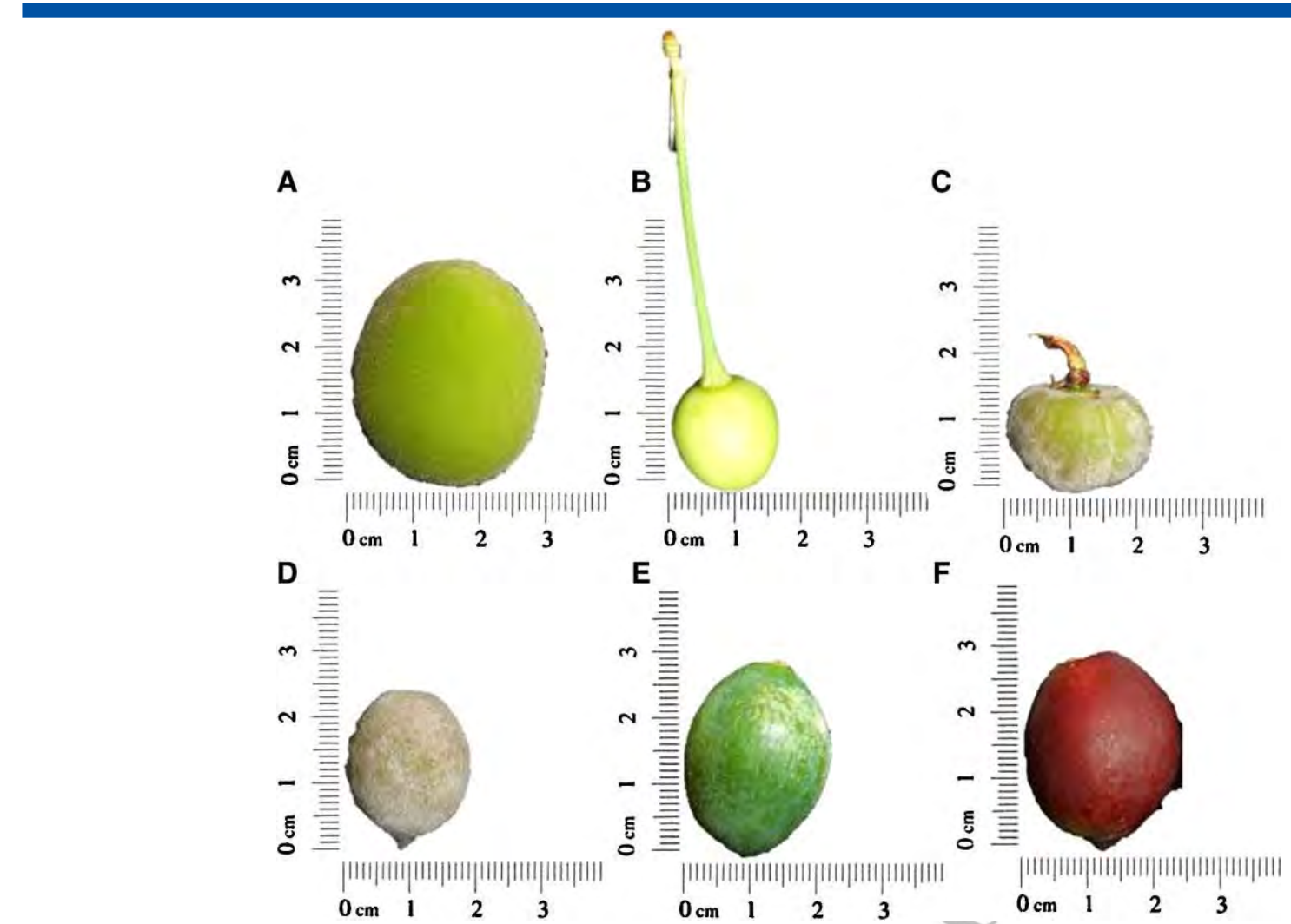

Figure 1. Visual appearance of the stone fruits on the date of thinning. (A)apricotcv. Pink Cot; (B) cherry cv. 20-09; (C) flat peach cv. UFO-3; (D) peach cv. Royal Glory; (E) plum cv. Tolosa; (F) nectarine cv. Laura.

\section{Phenolic compounds}

\section{Total phenoliccontent}

The TPC was determined by the Folin-Ciocalteu method ${ }^{21}$ with some modifications. An aliquot $(1 \mathrm{~mL})$ of extract or standard solution $\left(0-250 \mathrm{mg} \mathrm{L}^{-1}\right)$ of gallic acid (Sigma, St. Louis, MO, USA) was added to a $10 \mathrm{~mL}$ volumetric flask and mixed with $1 \mathrm{~mL}$ of Folin-Ciocalteu reagent. After $5 \mathrm{~min}, 1 \mathrm{~mL}$ of $7.5 \%$ sodium carbonate solution was added and the solution diluted to $10 \mathrm{~mL}$ with deionised water. After incubation for $60 \mathrm{~min}$ at room temperature in darkness, the absorbance was determined at $760 \mathrm{~nm}$ with a spectrophotometer (Unicam, Waltham, MA, USA). TPC was expressed as $\mathrm{mg}$ gallic acid equivalents (GAE) per $100 \mathrm{~g}$ dry weight(DW)

\section{Total flavonoid content}

The TFC of the extracts was determined using a colorimetric assay ${ }^{22}$ with some modifications. Briefly, atzerotime $0.1 \mathrm{~mL}$ of $5 \%$

$\mathrm{NaNO}_{2}$ (w/v) was added to $0.5 \mathrm{~mL}$ of extract or standard solution. After $5 \mathrm{~min}, 0.1 \mathrm{~mL}$ of $10 \% \mathrm{AlCl}_{3}(\mathrm{~W} / \mathrm{v})$ was addedandafter6min, $0.6 \mathrm{~m}$ Lof 1 mo $\mathrm{m}^{-1} \mathrm{~L}^{-1} \mathrm{NaH}$ wasadded andimmediately diluted with' differentconcentrations $\left(0-100 \mathrm{mgL}^{-1}\right)$ of catechin(Sigma)asthe standard. Absorbance of the pink mixture samples was measured with a spectrophotometer at $510 \mathrm{~nm}$ and the TFC was expressed atmg catechinequivalents(CE) per $100 \mathrm{~g} \mathrm{DW}$. 57 Was

\section{Identification of phenols by HPLC-DAD-MS" $/ E S$ I}

For the identification of phenolic compounds, $0.1 \mathrm{~g}$ of lyophilised fruit powder was extracted with $1 \mathrm{~mL}$ of methanol/water/formic acid $(80: 19: 1, \mathrm{v} / \mathrm{v})$ by sonication for $30 \mathrm{~min}$. The resulting extract was centrifuged and filtered through a $0.22 \mu \mathrm{m}$ PVDF filter. Chromatographic analyses were carried out on a LiChrocart C18 column $(250 \times 4$ $\mathrm{mm}, 5 \mu \mathrm{m}$ particle size; Merck, Darmstadt, Germany). The mobile phase was composed of two solvents: water with formic acid (1\%) (A) and methanol $(B)$ starting with $5 \% \mathrm{~B}$ and using a gradient to obtain $50 \% \mathrm{~B}$ at $22 \mathrm{~min}$ and $90 \% \mathrm{~B}$ at $27 \mathrm{~min}$, using this isocratic solution for $1 \mathrm{~min}$. The flow rate was $500 \mu \mathrm{L} \mathrm{min}{ }^{-1}$ and the injection volume was $5 \mu \mathrm{L}$. Spectral data from all peaks were accu- mulated in the range $200-400 \mathrm{~nm}$. Chromatograms were recorded at 320 and $360 \mathrm{~nm}$. The HPLC-DAD-MS $/ E S I$ analyses were carried out in an Agilent 117 HPLC 1200 series (Agilent Technologies, Wald- bronn, Germany) equipped with a binary pump (model G1376A), an autosampler (model G1377A) refrigerated at $4^{\circ} \mathrm{C}$ (model G1330B), a degasser (model G1379B), and a photodiode array detector (model 120 G1315D). The HPLC system was controlled by ChemStation software (Agilent, v.B.01.03-SR2). The mass detector was a Bruker ion trap spectrometer (model HCT Ultra) equipped

with an electrospray ionisation interface controlled by software (LCMSD, Agilent, v. 6.1). The ionisation conditions were $300^{\circ} \mathrm{C}$

and $4.0 \mathrm{kV}$ for capillary temperature and voltage, respectively. The nebuliser pressure and flow rate of nitrogen were $5.0 \mathrm{psi}$ and $3 \mathrm{~L} \mathrm{~min}{ }^{-1}$, respectively. The full scan mass covered the range from $\mathrm{m} / \mathrm{z} 100$ up to $\mathrm{m} / \mathrm{z}$ 1200 and the target mass was adjusted to 350 . Collision-induced fragmentation experiments were performed in the ion trap using helium as the collision gas, with voltage ramping cycles from 0.3 up to $2 \mathrm{~V}$. Mass spectrometry data were acquired in the negative mode and the $M^{n}$ was carried out in the automatic mode. The identification of the peaks was carried out by the extracted ion-chromatograms of the ion current at $\mathrm{m} / \mathrm{z}$ values corresponding to the $[\mathrm{M}-\mathrm{H}]^{-}$ions of the individual inves- tigated compounds, as well as theirfragmentation. Quantification 
Table 2. Total phenol content, total flavonoid content, DPPH scavenging and FRAP assay of six thinned stone fruits

\begin{tabular}{llccc} 
Species & Cultivar & TPC $\left(\mathrm{mg} \mathrm{GAE} \mathrm{g}^{-1}\right)$ & TFC $\left(\mathrm{mg} \mathrm{CE} \mathrm{g}^{-1}\right)$ & DPPH scavenging (mg TE g $\left.{ }^{-1}\right)$ \\
\hline Apricot & Pink Cot & $9.32 \pm 0.84^{\mathrm{e}}$ & $7.72 \pm 1.13^{\mathrm{f}}$ & $31.93 \pm 2.30^{\mathrm{d}}$ \\
Cherry & $20-09$ & $13.29 \pm 1.42^{\mathrm{d}}$ & $10.24 \pm 1.38^{\mathrm{e}}$ & $18.83 \pm 2.59^{\mathrm{e}}$ \\
Flat peach & UFO-3 & $35.03 \pm 1.58^{\mathrm{b}}$ & $33.04 \pm 2.48^{\mathrm{b}}$ & $80.44 \pm 4.88^{\mathrm{b}}$ \\
Peach & Royal Glory & $15.79 \pm 1.65^{\mathrm{d}}$ & $12.62 \pm 1.99^{\mathrm{d}}$ & $17.01^{\mathrm{b}}$ \\
Plum & Tolosa & $25.70 \pm 2.85^{\mathrm{c}}$ & $22.82 \pm 3.33^{\mathrm{c}}$ & $21.33 \pm 1.35^{\mathrm{b}}$ \\
Nectarine & Laura & $67.43 \pm 3.54^{\mathrm{a}}$ & $56.97 \pm 2.56^{\mathrm{a}}$ & $63.13 \pm 5.28^{\mathrm{c}}$ \\
\hline
\end{tabular}

The samples wereanalysed in triplicate and the results are presented as mean values \pm standard deviation of 2 years. Values are given on a dry weight (DW) basis.

Different letters in the same column indicate significant differences $(P<0.05)$.

of the identified analytes was performed by HPLC-DAD using the external standard methods with calibration graphs, as a function of concentration based on peak area, detected at the wavelength corresponding to the maximum absorbance (280 for flavan-3-ols, 320 for hydroxycinnamic acids and 360 for flavonols). Flavan-3-ols were quantified as catechin (Sigma), hydroxycinnamic acids as chlorogenic acid (5-0-caffeoylquinic acid) (Sigma) and flavonoids as quercetin-3-rutinoside (Sigma). The identification and quantifi- cation of phenols was performed only in the samples of 2014

\section{Determination of proanthocyanidin using phloroglucinol}

The procedure ${ }^{23}$ used was started by preparing a $0.1 \mathrm{~mol} \mathrm{~L}^{-1} \mathrm{HCl}$ $(37 \%)$ methanol solution (solution A). Solution B was then prepared by dissolving $120 \mathrm{mg}$ of phloroglucinol in $2.4 \mathrm{~mL}$ of solution A. Finally, solution $\mathrm{C}$ was prepared dissolving $20 \mathrm{mg}$ of ascorbic acid in $2 \mathrm{~mL}$ of solution $\mathrm{B}$. The reaction started adding $800 \mu \mathrm{L}$ of solution C to $50 \mathrm{mg}$ of the lyophilised samples. They were vortexed to completely dissolve the powder and then incubated at $50^{\circ} \mathrm{C}$ for $20 \mathrm{~min}$. The reaction was stopped by placing the samples in an ice bath and by diluting the reaction medium with $1 \mathrm{~mL}$ of a $40 \mathrm{mmol} \mathrm{L}^{-1}$ sodium acetate solution. The samples were centrifuged at $4000 \mathrm{rpm}$ during $10 \mathrm{~min}$ at $5^{\circ} \mathrm{C}$ and then filtered with $45 \mu \mathrm{m}$ nylon filter membrane. The samples $(10 \mu \mathrm{L})$ were then analysed by the reversed phase on an 1100 series HPLC-DAD system (Agilent Technologies). This was equipped with a G1312A binary pump, a G1313A autosampler, a G1315B photodiode array detector, controlled by the Agilent software v. A.08.03, and a G1322A degasser. The column was an Atlantis dC18 (particle size $5 \mu \mathrm{m}, 4,6 \times 250 \mathrm{~mm}$ ) purchased from Waters (Barcelona, Spain). The HPLC was coupled to an ion-trap mass spectrometer equipped with an electrospray ionisation $\operatorname{system}(\mathrm{ESI})$. The heated capillary

and voltage were maintained at $350 \quad \mathrm{C}$ and $4 \mathrm{kV}$, respectively. Massscan(MS)andMS/MS daughter spectrawere measured from $\mathrm{m} / \mathrm{z} 100$ to 1200 . Collision-induced fragmentation experiments were performed in theion trap using helium as the collision gas, and the collision energy was set at $50 \%$. Mass spectrometry data were acquired in the negative ionisation modes. The mobile phase was awater/acetic acid $(97.5: 2.5 \mathrm{v} / \mathrm{v})(\mathrm{A})$ and acetonitrile $(\mathrm{B})$ mixture. The flow rate was $1.0 \mathrm{~mL} \mathrm{~min}^{-1}$ and the linear gradient applied was: $3 \%$ B at $0 \mathrm{~min}, 9 \% \mathrm{~B}$ at $5 \mathrm{~min}, 16 \% \mathrm{~B}$ at $15 \mathrm{~min}$, $50 \% \mathrm{~B}$ at $45 \mathrm{~min}$, the same gradient until $52 \mathrm{~min}$, followed by washing and reconditioning the column with $3 \%$ B until $57 \mathrm{~min}$. A chromatogram was recorded at $280 \mathrm{~nm}$. The external standard was epicatechin (Sigma) and catechin (Sigma). The results were expressed as $\mathrm{mg} \mathrm{g}^{-1} \mathrm{DW}$ and the apparent mean degree of polymerisation (mDP) was also determined. ${ }^{24}$ The quantification of proanthocyanidins was performed only in the samples of 2014.

\section{Antioxidant activity}

\section{2,2-Diphenyl-1-picrylhydrazyl scavenging}

$\mathrm{DPPH}$ is a stable azo free radical. Its colour changes from violet to yellow when itis reduced by the electron donation process. ${ }^{25}$ Briefly, 900 $\mu \mathrm{L}$ of diluted extract were mixed with $900 \mu \mathrm{L}$ of DPPH $\left(133 \mu \mathrm{mol} \mathrm{L}^{-1}\right.$ in methanol; Sigma). The free radical scavenging activity was evaluated by measuring the variation in absorbance at $515 \mathrm{~nm}$ after 150 min of reaction and the results were expressed as $\mathrm{mg}$ of Trolox equivalents (TE) 100 $\mathrm{g}^{-1} \mathrm{DW}$.

Ferric reducing antioxidant power assay

The FRAP assay is based on the ability of $\mathrm{Fe}^{3+}$ to form a Fe ${ }^{2+}-\mathrm{TPTZ}$ complex, and measuring the blue colour generated in the sample. ${ }^{26}$ The FRAP solution was prepared by mixing $25 \mathrm{~mL}$ acetate buffer (300 mmol L-1, pH 3.6), $2.5 \mathrm{~mL}$ TPTZ solution (2,4,6-tripyridyl-striazine, $10 \mathrm{mmol} \mathrm{L}^{-1}$ in $40 \mathrm{mmol} \mathrm{L}^{-1} \mathrm{HCl}$ ) and

$2.5 \mathrm{~mL} \mathrm{FeCl}_{3} \cdot 6 \mathrm{H}_{2} \mathrm{O}\left(20 \mathrm{mmol} \mathrm{L}^{-1}\right)$. Then, $150 \mu \mathrm{L}$ of FRAP solution was allowed to react with $20 \mu \mathrm{L}$ of each extract in the well of a 96-well polypropylene plate (MIDSCI, Valley Park, MO, USA). Absorbance at $595 \mathrm{~nm}$ was measured after $30 \mathrm{~min}$ in a microplate reader (Tecan Trading AG, Männedorf, Switzerland). The standard solution $\left(0-1000 \mu \mathrm{mol} \mathrm{L}^{-1}\right)$ was made with Trolox (Sigma) and the results were expressed as $\mathrm{mg}$ TE $100 \mathrm{~g}^{-1} \mathrm{DW}$.

\section{Statistical analysis}

All samples were analysed in triplicate per year and the results were presented as mean values \pm standard deviation of the two years. Statistical analyses were performed using a one-way ANOVA test and the significance of the difference between means was determined by Duncan's multiple range test $(P<0.05)$. Corre- lations were calculated according to Pearson's test at $P 0.01$. $\leq$ Statistical analyses were performed using the Statistical Pack- age for the Social Science (SPSS) software version 22.0 (SPSS, Chicago, IL, USA).

\section{RESULTS AND DISCUSSION}

Total polyphenols and identification of individual phenols Table2shows the total phenoland flavonoid contents ofthinned fruits. Nectarine was the fruit with the highest content of total phenols $\left(67.43 \mathrm{mg} \mathrm{GAE} \mathrm{g}^{-1} \mathrm{DW}\right)$, followed by flat peach $(35.03 \mathrm{mg}$

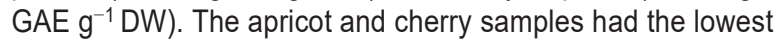
content(9.32and $13.29 \mathrm{mg} \mathrm{GAEg}^{-1} \mathrm{DW}$, respectively). This pattern was very similar for the TFC $\left(R^{2}=0.995\right)$. The highest values were obtainedfornectarine $\left(56.97 \mathrm{mg} \mathrm{CE}^{-1} \mathrm{DW}\right)$ while the lowestwere for apricot $\left(7.72 \mathrm{mg} \mathrm{CE} \mathrm{g}^{-1} \mathrm{DW}\right)$. 

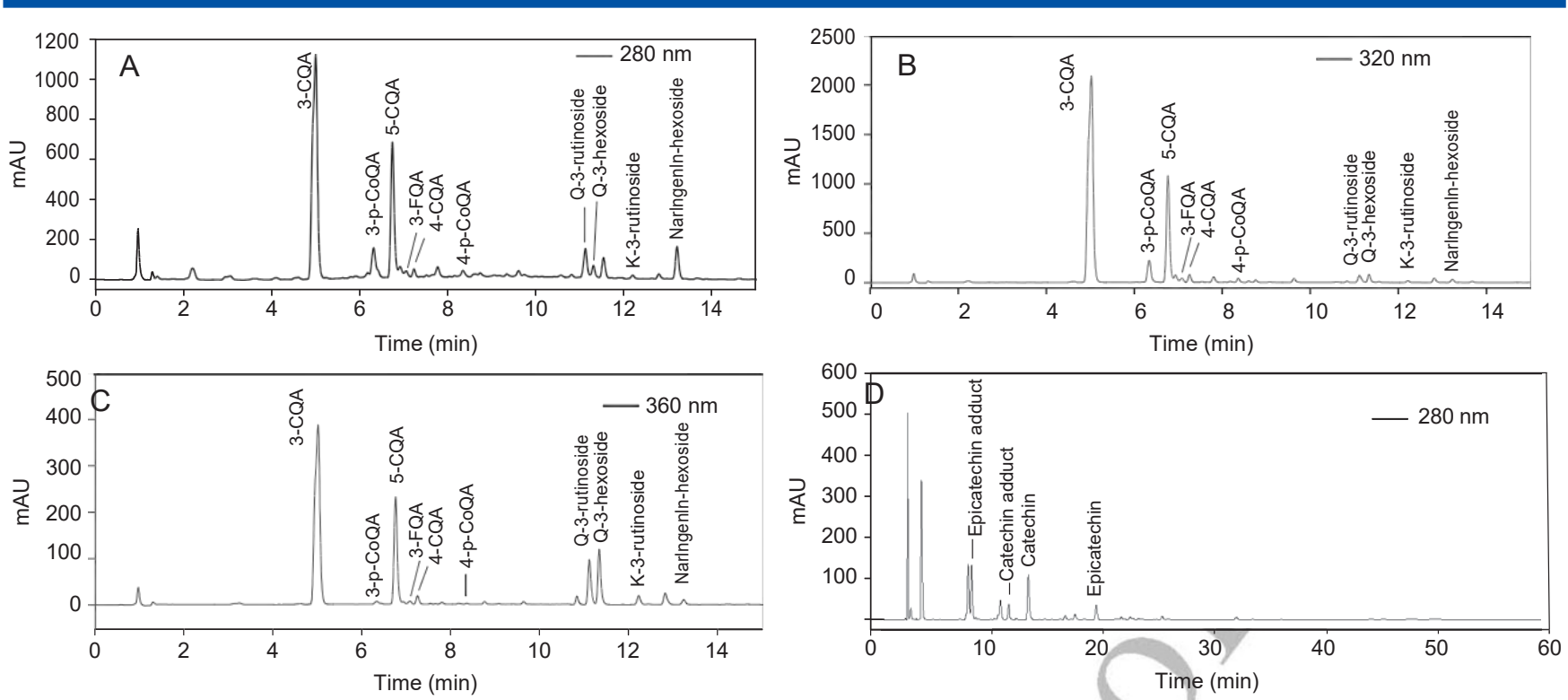

Figure 2. Example of chromatograms of thinned nectarine obtained by HPLC-MS at (A) $280 \mathrm{~nm}$, (B) $320 \mathrm{~nm}$ and (C) $360 \mathrm{~nm}$ after $80 \%$ methanol extraction for quantification of individual phenols and at (D) $280 \mathrm{~nm}$ after acid catalysis with phloroglucinol for quantification of proanthocyanidins. 3-CQA, neochlorogenic acid; 3-p-CoQA, 3-p-coumaroylquinic acid; 5-CQA, chlorogenic acid; 3-FQA, 3-feruloylquinic acid; 4-CQA, 4-caffeoylquinic acid; 4-p-CoQA, 4-p-coumaroylquinic acid; Q-3-rutinoside, quercetin-3-rutinoside; Q-3-hexoside, quercetin-3-hexoside; K-3-rutinoside, kaempherol-3 rutinoside; narigenin-hesoxide.
It is difficult to compare these results with those found in the literature because this study is the first report concerning compounds in thinned stone fruits. The results have therefore been compared with the amounts presentinotherunripe fruits and by-products. The TPC and TFC obtained for thinned fruits are similar to those observed in fruits at an immature development stage such as Brazilian cherries (Eugenia uniflora L.), with 41.4 and $51.8 \mathrm{mg} \mathrm{GAE} \mathrm{g}^{-1} \mathrm{DW}$ for red and purple cultivars, respectively, ${ }^{12}$ and calamondin peel with $25.7 \mathrm{mg} \mathrm{GAE} \mathrm{g}^{-1} \mathrm{DW}$ and $7.0 \mathrm{mg} \mathrm{CE} \mathrm{g}^{-1}$ DW. ${ }^{11}$ Forindustrial by-products, theoptimisation of the extraction of total phenolsandflavonoids ingrapestems $\left(20\right.$ minat $60^{\circ} \mathrm{C}$ with ethanol $40 \%$ )ledto68.8 $\mathrm{mg} \mathrm{GAEg}^{-1} \mathrm{DW}$ and $68.2 \mathrm{mgCEg}^{-1} \mathrm{DW}$, respectively. ${ }^{27}$ However, the majority of the fruit by-products had lower contents than ours, for example apple pomace (4.8mg GAE $\left.\mathrm{g}^{-1} \mathrm{DW}\right)$, orange bagasse $\left(8.6 \mathrm{mg} \mathrm{GAE} \mathrm{g}^{-1} \mathrm{DW}\right)$, passion fruit peel $\left(6.9 \mathrm{mg} \mathrm{GAE} \mathrm{g}^{-1} \mathrm{DW}\right),{ }^{28}$ banana peel $\left(9.3 \mathrm{mg} \mathrm{GAE} \mathrm{g}^{-1} \mathrm{DW}\right),{ }^{2}$ onion by-products $\left(4.1 \mathrm{mg} \mathrm{GAE} \mathrm{g}^{-1} \mathrm{DW}\right),{ }^{29}$ rice bran $\left(3.5 \mathrm{mg} \mathrm{GAE} \mathrm{g}^{-1}\right.$ DW), ${ }^{30}$ etc. Only certain by-products from tropical fruits had high TFC such as avocado (82.0 $\mathrm{mg} \mathrm{GAE} \mathrm{g}^{-1} \mathrm{DW}$ ) and mango (117.0 mg GAE g ${ }^{-1}$ DW) seeds. ${ }^{2}$ identify the individual phenolic content Preliminary studies with different solvents were carried out in order to choose the best option to extract the highest amounts of individual phenols. Finally, two extractions were used separately: $80 \%$ methanol for flavonols, phenolic acids and hydroxycinnamic acids whereas proanthocyanidinswere better extracted afteracid

As can be seen in Table 3 , the sum of total phenolic acids was the highest in nectarine $\left(75.92 \mathrm{mg} \mathrm{g}^{-1} \mathrm{DW}\right)$, followed by flat peach 58 (55.95 mgg $\left.{ }^{-1} \mathrm{DW}\right)$, plum $\left(33.59 \mathrm{mg} \mathrm{g}^{-1} \mathrm{DW}\right)$, peach $\left(29.59 \mathrm{mgg}^{-1}\right.$ DW) and cherry (15.46 $\left.\mathrm{mg} \mathrm{g}^{-1} \mathrm{DW}\right)$, while apricot was the lowest $\left(9.97 \mathrm{mgg}^{-1} \mathrm{DW}\right)$. These results, although higher, are very similar to the values obtained for the TFC using the Folin-Ciocalteu reagent.
Apart from the TPC and TFC, it is obviously of interest to catalysis (Fig. 2).
Flavan-3-ols

No proanthocyanidins were detected when a general method for the identification of phenols was used. However, with an acid catalysis in the presence of an excess of phloroglucinol, an increase in the quantitative conversion of proanthocyanidins into their constitutive sub-units was achieved. This could be the reason why the TFC was lower than the amounts of phenols identified, since in the latter case the concentration of proanthocyanidins after acid catalysis has been taken into account.

The terminal sub-units were flavanol-3-ol monomers, while the extension sub-units reacted with phloroglucinol giving phloroglucinol adducts. ${ }^{24}$ The products formed and identified after acid-catalysed cleavage of proanthocyanidins from stone fruits were catechin and epicatechin as terminal sub-units and epicatechin-phloroglucinol as an extension unit.

Proanthocyanidins after acid catalysis were by far the most abun- dant compounds identified in thinned fruits, ranging from 3.04 in apricot to $59.89 \mathrm{mgg}^{-1} \mathrm{DW}$ in nectarine (Table 4). These results are consistent with those reported by other authors ${ }^{31,32}$ in which the proanthocyanidins were the compounds with the highest contents. As indicated in Table 4 , catechin was the compound which had the highest concentration in the studied fruits (ranging from 1.03 in apricots to $20.52 \mathrm{mg} \mathrm{g}^{-1} \mathrm{DW}$ in nectarines) except for flat peaches in which case it was epicatechin (12.67 $\mathrm{mg} \mathrm{g}^{-1} \mathrm{DW}$ ). However, high amounts of epicatechin extension units (between $20.1 \%$ and $72.1 \%$ of total proanthocyanidins) werealso detected.

A comparison of the content of PAs is difficult due to both the lack of research into the content of these compounds in thinned fruits and the different methodologies used to quantify the com- pounds. Some of these under-estimate the results because only monomers, dimers and trimers are detected and no conversion into sub-units is done. Some authors ${ }^{33}$ have studied the con- centrations of proanthocyanidins in common foods, detecting the highest contents in cinnamon $(89.6 \mathrm{mg}$ $\left.\mathrm{g}^{-1} \mathrm{DW}\right)$, sorghum bran $\left(39.6 \mathrm{mg} \mathrm{g}^{-1} \mathrm{DW}\right)$ and grape seeds $\left(35.3 \mathrm{mg} \mathrm{g}^{-1}\right.$ DW). Among fruits, plums (17.1 $\left.\mathrm{mg} \mathrm{g}^{-1} \mathrm{DW}\right)$, red delicious apple $(9.5 \mathrm{mg}$ $g^{-1}$ 
Table 3. Identification and quantification of phenolic compounds in six thinned stone fruits $\left(\mathrm{mg} \mathrm{g}^{-1} \mathrm{DW}\right)$

\begin{tabular}{|c|c|c|c|c|c|c|}
\hline Phenolic compound & $\begin{array}{l}\text { Apricot cv. } \\
\text { Pink Cot }\end{array}$ & $\begin{array}{l}\text { Cherry cv. } \\
20-09\end{array}$ & $\begin{array}{l}\text { Flat peach cv. } \\
\text { UFO-3 }\end{array}$ & $\begin{array}{c}\text { Peach } \\
\text { cv. Royal Glory }\end{array}$ & $\begin{array}{c}\text { Plum } \\
\text { cv. Tolosa }\end{array}$ & $\begin{array}{l}\text { Nectarine cv. } \\
\text { Laura }\end{array}$ \\
\hline \multicolumn{7}{|l|}{ Flavan-3-ols } \\
\hline Catechin & ND & ND & ND & ND & ND & ND \\
\hline Epicatechin & ND & ND & ND & ND & ND & ND \\
\hline Proanthocyanidins $^{\dagger}$ & $3.04 \pm 0.08^{f}$ & $10.54 \pm 0.19^{d}$ & $33.47 \pm 4.16^{b}$ & $13.79 \pm 0.62^{\mathrm{C}}$ & $9.69 \pm 1.87 \mathrm{ed}$ & $59.89 \pm 3.64^{a}$ \\
\hline Total flavan-3-ols & 3.04 & 10.54 & 33.47 & 13.79 & 9.69 & 59.89 \\
\hline \multicolumn{7}{|l|}{ Flavonols } \\
\hline Quercetin-3-hexoside & ND & ND & $0.17 \pm 0.01^{a}$ & ND & ND & $0.22 \pm 0.05^{a}$ \\
\hline Quercetin 3-rutinoside & $0.23 \pm 0.01^{a}$ & $0.09 \pm 0.01^{c}$ & $0.18 \pm 0.02^{b}$ & $0.06 \pm 0.01^{d}$ & $0.15 \pm 0.02^{b}$ & $0.18 \pm 0.04^{\mathrm{ab}}$ \\
\hline Kaempherol-3-hexoside & ND & ND & ND & $0.04 \pm 0.01^{\mathrm{a}}$ & ND & ND \\
\hline Kaempherol-3-rutinoside & $0.03 \pm 0.00^{c}$ & $0.03 \pm 0.00^{c}$ & $0.09 \pm 0.01^{a}$ & $0.05 \pm 0.01^{b}$ & ND & $0.04 \pm 0.01^{b}$ \\
\hline Total flavonols & 0.26 & 0.12 & 0.44 & 0.15 & 0.15 & 0.44 \\
\hline \multicolumn{7}{|l|}{ Flavanones } \\
\hline Total flavanones & - & - & - & - & - & - \\
\hline \multicolumn{7}{|l|}{ Hydroxycinnamic acids } \\
\hline Neochlorogenic acid & $1.65 \pm 0.08^{d}$ & $1.88 \pm 0.33^{d}$ & $13.00 \pm 1.00^{\mathrm{ab}}$ & $8.43 \pm 1.22^{c}$ & $15.00 \pm 1.52^{a}$ & $10.75 \pm 2.38^{b c}$ \\
\hline Chlorogenic acid & $4.34 \pm 0.08^{c}$ & $0.31 \pm 0.02^{\mathrm{e}}$ & $7.04 \pm 0.53^{a}$ & $5.63 \pm 0.77^{b}$ & $3.62 \pm 0.44^{d}$ & $3.54 \pm 0.76^{d}$ \\
\hline Isochlorogenic acid & ND & $0.04 \pm 0.00^{c}$ & $0.23 \pm 0.02^{a}$ & $0.09 \pm 0.03^{b}$ & $0.07 \pm 0.01^{b}$ & ND \\
\hline 4-p-Coumaroylquinic acid & $0.18 \pm 0.03^{b}$ & $0.14 \pm 0.01^{c}$ & $0.19 \pm 0.01^{b}$ & $0.17 \pm 0.02^{b}$ & $0.15 \pm 0.02^{b c}$ & $0.84 \pm 0.19^{a}$ \\
\hline 4-Caffeoylquinic acid & $0.22 \pm 0.01^{\mathrm{c}}$ & $0.11 \pm 0.01^{d}$ & $0.14 \pm 0.02^{d}$ & $0.63 \pm 0.09^{b}$ & $3.64 \pm 0.47^{a}$ & $0.22 \pm 0.05^{c}$ \\
\hline 3-Feruloylquinic acid & $0.16 \pm 0.01^{\mathrm{c}}$ & $0.03 \pm 0.00^{d}$ & $0.27 \pm 0.03^{a}$ & $0.18 \pm 0.02^{b c}$ & $0.21 \pm 0.03^{a b}$ & $0.13 \pm 0.03^{c}$ \\
\hline 3-p-Coumaroylquinic acid & $0.12 \pm 0.01^{e}$ & $2.29 \pm 0.17^{a}$ & $1.17 \pm 0.08^{b}$ & $0.52 \pm 0.08^{d}$ & $1.06 \pm 0.03^{c}$ & $0.11 \pm 0.05^{\mathrm{e}}$ \\
\hline Total hydroxycinnamic acids & 6.67 & 4.80 & 22.04 & 15.65 & 23.75 & 15.59 \\
\hline Total polyphenols identified & 9.97 & 15.46 & 55.95 & 29.59 & 33.59 & 75.92 \\
\hline
\end{tabular}

Table 4. Proanthocyanidins content in samples after acid catalysis in the presence of phloroglucinol, mean degree of polymerisation (mDP) and catechin and epicatechin content

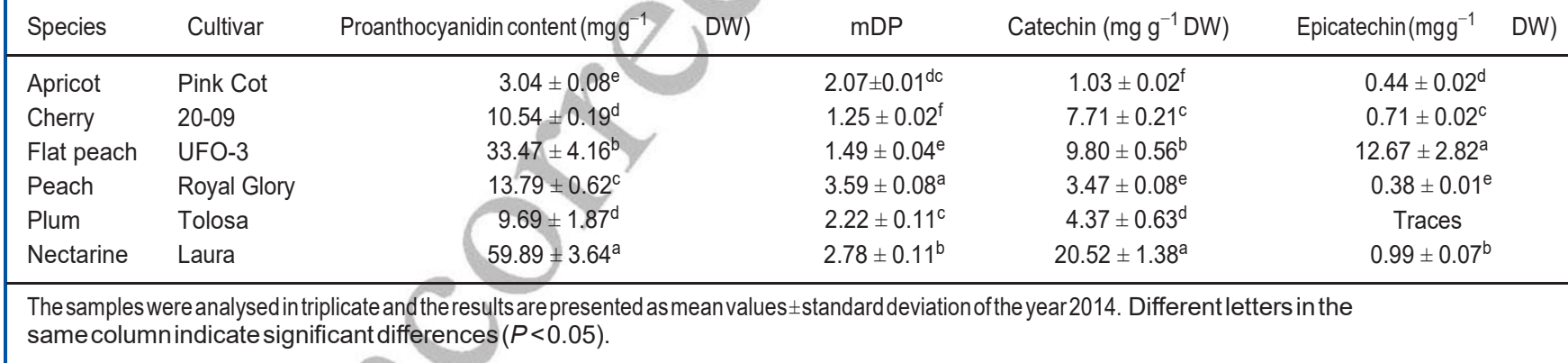

$\mathrm{DW})$, peaches $\left(5.8 \mathrm{mgg}^{-1} \mathrm{DW}\right)$, nectarines $\left(2.1 \mathrm{mgg}^{-1} \mathrm{DW}\right)$, apricots $\left(1.1 \mathrm{mgg}^{-1} \mathrm{DW}\right)$ and cherries $\left(0.4 \mathrm{mgg}^{-1} \mathrm{DW}\right)$ were analysed. These contents are lower than those detected in our study, although no acid catalysis was used. The number of studies with acid catalysis is scarce, although proanthocyanidin contents of $1.7-5.3 \mathrm{mg} \mathrm{g}^{-1} \mathrm{DW}$ have been reported in apples, ${ }^{32} 0.12 \mathrm{mg} \mathrm{mL}^{-1}$ in American cranberry juice ${ }^{34}$ and $120 \mathrm{mg} \mathrm{g}^{-1} \mathrm{DW}$ in black chokeberry industrialby-products. ${ }^{35}$

The bioavailability of proanthocyanidins is largely influenced by their degree of polymerisation (mDP). ${ }^{36,37}$ The oligomeric and polymeric forms pass intact through the gastrointestinal tract and reach the colon, where they must be transformed by the intestinal microbiota before absorption. Only monomeric flavanols are readily absorbed in the small intestine. Therefore, a low $\mathrm{mDP}$ is desirable. ${ }^{38}$ The mDP in our thinned fruits was between 1.25 in cherry and 3.59 in peach (Table 4). These values are lower than those reported in other fruits such as apples $(5.7-7.1),{ }^{39}$ grapes $(4.8-22.1)^{40}$ or brown soybean seeds (30). ${ }^{41}$ Thus, thinned fruits that have proanthocyanidins with small $\mathrm{mDP}$ might be used to obtain extracts with high bioavailability.

\section{Flavonols}

A total of four flavonols (kaempherol-3-hexoside, kaempherol-3rutinoside, quercetin-3-hexoside and quercetin 3-rutinoside) 
were identified in the different thinned fruits (Table 3). Quercetin 3-rutinoside was found in all the fruits tested, with the highestconcentrationsinapricot $\left(0.23 \mathrm{mgg}^{-1} \mathrm{DW}\right)$ and nectarine $\left(0.18 \mathrm{mgg}^{-1}\right.$ DW). These values are similar to those obtained in immature peaches $\left(0.01-0.26 \mathrm{mg} \mathrm{g}^{-1} \mathrm{DW}\right)^{10}$ and grape by-products (skin, $0.11 \mathrm{mgg}^{-1} \mathrm{DW}$; pomace, $0.08 \mathrm{mg} \mathrm{g}^{-1} \mathrm{DW}$; stems, $0.03 \mathrm{mgg}^{-1} \mathrm{DW}$; seeds, traces) ${ }^{42}$ Kaempherol-3-rutinosidewasidentified inall the fruits except in plum. The highest content was found in flat peach $\left(0.09 \mathrm{mg} \mathrm{g}^{-1} \mathrm{DW}\right)$, being 10 times higher than the ones detected in the skin of different. ${ }^{23}$ Meanwhile, quercetin-3-hexoside was only identified in nectarine $\left(0.22 \mathrm{mgg}^{-1} \mathrm{DW}\right)$ and flat peach $\left(0.17 \mathrm{mg} \mathrm{g}^{-1} \mathrm{DW}\right)$ and kaempherol-3-hexoside only in flat peach $\left(0.17 \mathrm{mg} \mathrm{g}^{-1} \mathrm{DW}\right)$. The greatest content of flavonols was found in flat peach and nectarine, both with $0.44 \mathrm{mg} \mathrm{g}^{-1} \mathrm{DW}$. The flavonols (particularly kaempferol and quercetin) are considered to be antioxidant, anti-inflammatory, anticarcinogenic, anti-thrombotic and antiviral compounds. ${ }^{13,43} 18$

\section{Flavanones}

Although not quantified, naringenin-hexoside wasidentified in two fruits, the flat peach and nectarine. Flavanones occur almost exclusively in citrus fruits and are the major flavonoids in oranges and mandarins, although they havealso been detected in grapefruit and tomato peel. ${ }^{44}$ Therefore, flat peach and nectarine thinned fruits might be considered as a new source of flavanones. These compounds have been shown to inhibit chemically induced mammary, urinary bladder, and colon carcinogenesis in laboratory animals. They also act as antioxidants, regulate apolipoprotein B secretion by HepG2 cells, possibly through the inhibition of cholesterol ester synthesis, decrease low-density lipoprotein levels and hepatic cholesterol levels in plasma rabbits, and increase high-density lipoprotein levels in hypercholesterolaemic human subjects. ${ }^{44}$

\section{Hydroxycinnamic acids}

A total of seven hydroxycinnamic acids (neochlorogenic acid chlorogenic acid, isochlorogenic acid, 4- $p$-coumaroylquinic acid, 4-caffeoylquinic acid, 3-feruloylquinic acid 5-p-coumaroylquinic acid) were identified in the thinned fruits (Table 3). The total hydroxycinnamic acids identified ranged from $75.92 \mathrm{mgg}^{-1} \mathrm{DW}$ fornectarine to $9.97 \mathrm{mgg}^{-1} \mathrm{DW}$ for apricot. All of them were quantified in cherry, flat peach, peach and plum but isochlorogenic acid was not detected in apricot or nectarine. The main individual phenols identified (without acid catalysis) were neochlorogenic acid, ranging from $1.65 \mathrm{mgg}^{-1} \mathrm{DW}$ for apricotto $15.00 \mathrm{mgg}^{-1} \mathrm{DW}$ forplum, and chlorogenicacid, from $0.44 \mathrm{mg} \mathrm{g}^{-1} \mathrm{DW}$ for apricot to $7.04 \mathrm{mg} \mathrm{g}^{-1} \mathrm{DW}$ for flat peach. These in fruit by-products. Thus, in the pulp ofimmature peaches the values ranged from 0.64 to $7.64 \mathrm{mgg}^{-1} \mathrm{DW}$ for neochlorogenic acid and from 1.59 to $5.48 \mathrm{mg} \mathrm{g}^{-1} \mathrm{DW}$ for chlorogenic acid ${ }^{10}$ while in the skin of nectarines $1.47 \mathrm{mg} \mathrm{g}^{-1} \mathrm{DW}$ for chlorogenic acid and $0.27 \mathrm{mgg}^{-1} \mathrm{DW}$ forneochlorogenic acid were quantified. ${ }^{45}$ Among the other compounds highlighted were isochlorogenic acid in flat peach $\left(0.23 \mathrm{mgg}^{-1} \mathrm{DW}\right), 4-p$-coumaroylquinic acid in nectarine $\left(0.84 \mathrm{mg} \mathrm{g}^{-1} \mathrm{DW}\right), 4$-caffeoylquinic acid in plum $\left(3.64 \mathrm{mg} \mathrm{g}^{-1} \mathrm{DW}\right)$, 3-feruloylquinic acid in flat peach $\left(0.27 \mathrm{mg} \mathrm{g}^{-1}\right.$ DW) and 5-p-coumaroylquinic acid in cherry $\left(2.29 \mathrm{mgg}^{-1} \mathrm{DW}\right)$. These compounds are very important for human health because they may exhibit antioxidative, antihypertensive, antibacterial, anti-tumour and anti-inflammatory properties. They may also be concentrations are higher than those reported by otherauthors promising precursor compounds for the development of medical products that can resist HIV-1 RNase. ${ }^{46}$

\section{Antioxidant activity}

The antioxidant activity of the thinned fruit extracts was mea- sured by two different methods: DPPH scavenging and FRAP assay (Table 2). For DPPH scavenging, the behaviour was very similar to that obtained in TPC, with a high correlation between both assays $\left(R^{2}=0.965\right)$. The highestvalues were obtained for nectarine $\left(133.30 \mathrm{mg} \mathrm{TE} \mathrm{g}^{-1} \mathrm{DW}\right)$ while the

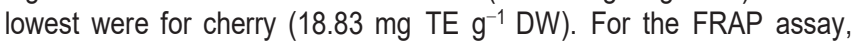
although the highest and lowest values were also achieved for nectarine (30.42 $\mathrm{mg} \mathrm{TE} \mathrm{g}^{-1} \mathrm{DW}$ ) and cherry (17.50 $\left.\mathrm{mg} \mathrm{TE} \mathrm{g}^{-1} \mathrm{DW}\right)$, respectively, the differences between the other fruits were not significant $(P<0.05)$, although the corre- lation between the FRAP assayand TPC washigh $\left(R^{2}=0.826\right)$.

These variations between the two different antioxidant assays could be due to the existence of numerous radicals, the different physical and chemical characteristics of the oxidants and the different reaction mechanisms. The same effect has been found by other authors in papaya, pineapple and tamarind, ${ }^{47}$ guava,${ }^{26}$ apple, apricot, mandarin, oat, peach, plum, riceand wheat. ${ }^{48}$

Similar conclusions can be obtained when comparing the antiox- idant varieties of immature cherries has shown equal or lower concentrations ( 45.0 and $\left.42.6 \mathrm{mg} \mathrm{TE} \mathrm{g}^{-1} \mathrm{DW}\right)^{12}$ than the majority of our thinned fruits. The activity obtained with the FRAP assay in passion fruit peel $\left(4.4 \mathrm{mg} \mathrm{TE} \mathrm{g}^{-1} \mathrm{DW}\right)^{49}$ was much lower than that in our thinned samples. Therefore, if all the above authors conclude that the byproducts studied represent a source of antioxidant compounds, it seems clear that thinned fruits must be an important source of interesting compounds that may be used in the food, chemical and pharmaceutical industriesas antioxidants ${ }^{16}$ or anti-browning agents. ${ }^{14}$

\section{CONCLUSIONS}

All the thinned stone fruits analysed in this study are clearly a potential source of polyphenols $\left(>9.0 \mathrm{mg} \mathrm{GAE} \mathrm{g}^{-1} \mathrm{DW}\right.$ and $>7.0$ $\mathrm{mg} \mathrm{CE} \mathrm{g}{ }^{-1} \mathrm{DW}$ ) and antioxidant compounds (>18.0 $\mathrm{mg} \mathrm{TE} \mathrm{g}^{-1} \mathrm{DW}$ by DPPH scavenging and $>17.0 \mathrm{mg} \mathrm{TE} \mathrm{g}^{-1}$ DW by FRAP assay). Nectarine had the highest content of total phe- nols ( $67.43 \mathrm{mg} \mathrm{GAE}$ $\mathrm{g}^{-1} \mathrm{DW}$ ), total flavonoids (56.97 $\mathrm{mg} \mathrm{CE} \mathrm{g}^{-1} \mathrm{DW}$, respectively) and antioxidant activity revealed by both methods, DPPH scavenging (133.30 $\mathrm{mg} \mathrm{TE} \mathrm{g}^{-1} \mathrm{DW}$ ) and FRAP assay (30.42 $\left.\mathrm{mg} \mathrm{TE} \mathrm{g}^{-1} \mathrm{DW}\right)$. The main individual phenols iden- tified were catechin (cherry and nectarine), epicatechin (flat peach), chlorogenic acid (apricot) and neochlorogenic acid (flat peach, peach and plum), although 5-pcoumaroylquinic acid and 4-caffeoylquinic acid were also significant in cherry and plum, respectively. Proanthocyanidins are very abundant in these by-products and, due to their low mean degree of polymerisation, their bioavailability could be very high. Thus, thinned fruits might be used as antioxidants in foods or as a source of compounds with health related benefits that can be used in the pharmaceutical, cosmetic and food industries. Significant economic benefits could thus be obtained from these by-products.

\section{ACKNOWLEDGEMENTS}

This work was supported by the Department of Industry and Innovation of the Aragón Government, and the European Social activity of thinned fruits with other by-products. DPPH scav- enging of two 
Fund(Project229402/1-PlantFoodResearch Group). Theauthors gratefully acknowledge the support given by all staff at the CEBAS-CSIC institute, and especially to Alicia Marín for her help with the determination of individual phenols. 5

\section{REFERENCES}

1 Ayala-Zavala JF, Vega-Vega V, Rosas-Domínguez C, Palafox-Carlos $\mathrm{H}$ Villa-Rodríguez JA, Siddiqui MW, et al., Agro-industrial potential of exotic fruitbyproducts as a source of food additives. Food Res Int 44:1866-1874 (2011)

2 Ayala-Zavala JF, Rosas-Domínguez C, Vega-Vega V and GonzálezAguilar G, Antioxidant enrichment and antimicrobial protection of fresh-cut fruits using their own byproducts: Looking for integral exploitation. J Food Sci 75:175-181 (2010)

3 PineloM, FabbroPD, ManzoccoL, NuñezMJ and Nicoli MC, Optimization of continuous phenol extraction from Vitis vinifera byproducts. Food Chem 92:109-117 (2005)

4 Jaganath IB and Crozier A, Overview of health-promoting compounds infruitand vegetables, in Improving the Health-Promoting Properties of Fruit and Vegetable Products, ed. by Tomás-Barberán FA and Gil MI. Woodhead Publishing, Cambridge, pp. 3-37 (2008).

5 Yoshikawa FT and Johnson RS, Fruit thinning in Peaches, Plums and $\mathrm{JH}$ and Jhonson RS. Cooperative Extension, Division of Agriculture and Natural Resources, University of California, Oakland, pp. 56-59 (1989)

6 Nuncio-Jáuregui $N$, Nowicka $P$, Munera-Picazo S, Hernández F, Carbonell-Barrachina AA and Wojdyło A., Identification and quantification of major derivatives of ellagic acid and antioxidant properties of thinning and ripe Spanish pomegranates. J Funct Foods 12:354-364 (2015)

7 Martín B, TorregrosaA and García-Brunton J, Post-bloom thinning of peaches for canning with hand-held mechanical devices. Sci Hort 125:658 - 665 (2010)

8 Zheng $\mathrm{H}$, Kim Y and Chung S, A profile of physicochemical and antioxidant changes during fruit growth for the utilisation of unripe apples. Food Chem 131:106-110 (2012)

9 Dragovic-UzelacV, LevajB, MrkicV, BursacDand Boras M, The content of polyphenols and carotenoids in three apricot cultivars depending on stage of maturity and geographical region. Food Chem 102:966-975 (2007)

$10 \mathrm{LiuH}$, Cao J and Jiang W, Evaluation of physiochemical and antioxidant activitychangesduringfruiton-treeripening forthepotentialvalues of unripe

11 LouS, Lin Y, HsuY, Chiu Eand HoC, Soluble and insoluble phenolic compounds and antioxidant activity of immature calamondin affected by solvents and heat treatment. Food Chem 161:246-253 (2014).

12 Celli GB, Pereira-Netto AB and Beta T, Comparative analysis of total phenoliccontent, antioxidantactivity, andflavonoidsprofileoffruits from two varieties of Brazilian cherry (Eugeniauniflora L.) throughout the fruit developmental stages. Food Res Int 44:2442-2451(2011).

13 Manach C, ScalbertAandMorand C,Polyphenols:Food sourcesand

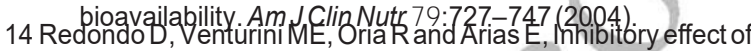
microwaved thinned nectarine extracts on polyphenol oxidase activity. Food Chem 197:603-610(2016).

15 Acosta-Estrada BA, Gutiérrez-Uribe JA and Serna-Saldívar SO, Bound phenolicsinfoods, Areview. Food Chem 152:46-55(2014)

16 CheynierV, Tomás-Barberán FAand Yoshida, K, Polyphenols: from plants to a variety of food and nonfood uses. J Agric Food Chem 63:7589-7594 (2015)

17 Somoza V, MolyneuxRJ, ChenZY, Tomás-Barberán Fand Hofmann, $T$, Guidelines for research on bioactive constituents, A journal of agricultural and fogd chemistry perspective. J Agric Food Chem

18 Spranger I, Sun B, Mateus AM, Freitas Vd and Ricardo-da-Silva JM, Chemical characterization and antioxidant activities of oligomeric and polymeric procyanidin fractions from grape seeds. Food Chem 108:519-532 (2008)

19 Zhang S, Cui Y, Li L, Li Y, Zhou P, Luo L, etal., Preparative HSCCC isolation of phloroglucinolysis products from grape seed polymeric proanthocyanidins as new powerful antioxidants. Food Chem
20 Chen X, Liang G, Chai W, Feng H, Zhou H, Shi Y, et al., Antioxidant and antityrosinase proanthocyanidins from Polyalthia longifolia leaves. J BiosciBioeng 118:583-587 (2014).

21 Singleton VL and Rossi JA, Colorimetry of total phenolics with phosphomolybdic - phosphotungstic acid reagents. Am J Enol Vitic 16:144-158(1965)

22 lacopini $P$, Camangi $F$, Stefani A and Sebastiani L, Antiradical poten- tial of ancient Italian apple varieties of Malus $\times$ domestica Borkh. in a peroxynitrite-induced oxidative process. J Food Comp Anal 23:518 524 (2010)

23 Vallejo F, Marín JG and Tomás-Barberán FA, Phenolic compound con- tent of fresh and dried figs (Ficus carica L.). Food Chem 130:485-492 (2012).

24 Kennedy JA and Jones GP, Analysis of proanthocyanidin cleavage prod- ucts following acid catalysis in the presence of excess phlorogluci- nol. J Agric Food Chem 49:1740-1746 (2001).

25 Llorach R, Martínez-Sánchez A, Tomás-Barberán FA, Gil MI and Ferreres F, Characterisation of polyphenols and antioxidant properties of five lettuce varieties and escarole. Food Chem 108:1028-1038(2008)

26 Thaipong K, Boonprakob U, Crosby K, Cisneros-Zevallos L and Hawkins Byrne $\mathrm{D}$, Comparison of ABTS, DPPH, FRAP, and ORAC assays for estimating antioxidant activity from guava fruit extracts. J Food Comp Anal 19:669$675(2006)$

27 Domínguez-Perles R, Teixeira Al, Rosa E and Barros Al, Assessment of (poly)phenols in grape (Vitis vinifera L.) stems by using food/pharma industry compatible solvents and response surface methodology. Food Chem 164:339-346 (2014).

28 Macagnan, FT, dos Santos LR, Roberto BS, de Moura FA, Bizzani M and da Silva LP, Biological properties of apple pomace, orange bagasse and passion fruit peel as alternative sources of dietary fibre. Bioact Carbohydr Diet Fibre 6:1-6 (2015)

29 Roldán E, Sánchez-Moreno C, de Ancos B and Cano MP, Characterisa- tion of onion (Allium cepa L.) by-products as food ingredients with antioxidant and antibrowning properties. Food Chem 108:907-916 (2008).

30 Wanyo $\mathrm{P}$, Meeso N and Siriamornpun S, Effects of different treatments on the antioxidant properties and phenolic compounds of rice bran and rice husk. Food Chem 157:457-463(2014)

31 Ceymann M, Arrigoni E, Schärer H, Bozzi Nising A and Hurrell RF, Identification of apples rich in health-promoting flavan-3-ols and phenolic acids by measuring the polyphenol profile. J Food Comp Anal 26:128$135(2012)$.

32 Jakobek L, García-Villalba R and Tomás-Barberán FA, Polyphenolic characterisation of old local applevarieties from Southeastern European region. $J$ Food Comp Anal 31:199-211 (2013).

33 Gu L, Kelm MA, Hammerstone JF, Beecher G, Holden J, Haytowitz D, et al., Concentrations of proanthocyanidins in common foods and estimations of normalconsumption.JNutr34:613-617(2014)

34 Lee J, Proanthocyanidin A2 purification and quantification of Ameri- can cranberry (Vaccinium macrocarpon Ait.)products. JFunctFoods 5:144$153(2013)$

35 Sójka M, Kołodziejczyk K and Milala J, Polyphenolic and basic chemical composition of black chokeberry industrial by-products. Ind Crops Prod 51:77-86 (2013)

36 de Pascual-Teresa S, Moreno DA and García-Viguera C, Flavanols and anthocyanins in cardiovascularhealth: A review of currentevidence. Int J Mol Sci 11:1679-1703 (2010)

37 Monagas M, Quintanilla-López JE, Gómez-Cordovés C, Bartolomé B and Lebrón-Aguilar R, MALDI-TOF MS analysis of plant proanthocyani- dins. A review. JPharm Biomed Anal 51:358-372(2010)

38 Fernández $\mathrm{K}$, Vega $\mathrm{M}$ and Aspé $\mathrm{E}$, An enzymatic extraction of proanthocyanidins from País grape seeds and skins. Food Chem 168:7 - 13 (2015).

39 Guyot S, Le Bourvellec C, Marnet N and Drilleau JF, Procyanidins are the most abundant polyphenols in dessert apples at maturity. LWT Food Sci Technol 35:289-291 (2002).

40 Sun B, Leandro C, Ricardo da Silva JM and Spranger I, Separation of grape and wine proanthocyanidins according to their degree of polymerization. JAgric Food Chem 46:1390-1396(1998).

41 Takahata Y, Ohnishi-Kameyama M, Furuta S, Takahashi M and Suda I, Highly polymerized procyanidins in brown soybean seed coat with a high radicalscavenging activity. J Agric Food Chem 49:5843-5847 (2001)

42 Jara-Palacios MJ, Hernanz D, González-Manzano, S, Santos-Buelga C, Escudero-Gilete ML and Heredia FJ, Detailed phenolic composition 
of white grape by-products by RRLC/MS and measurement of the

43 Park S, Artioxidantagctivity Talantanta 125:51-57.(2014) profiling of phenolics, anthocyanins and flavonols in cabbage (Brassica oleracea var. capitata). Ind CropsProd 60:8-14 (2014).

44 Erlund I, Review of the flavonoids quercetin, hesperetin, and naringenin. Dietary sources, bioactivities, bioavailability, andepidemiol- ogy. Nutr (2004)

45 Scattino C, Castagna A, Neugart S, Chan HM, Schreiner M, Crisosto $\mathrm{CH}$ et al., Post-harvest UV-B irradiation induces changes of phenol contents and corresponding biosynthetic gene expression in peaches and nectarines. Food Chem 163:51-60 (2014).

46 Naso LG, Valcarcel M, Roura-Ferrer M, Kortazar F, Salado C, Lezama L, et al., Promising antioxidant and anticancer (human breast cancer) oxidovanadium (IV) complex of chlorogenic acid. Synthesis, characterization and spectroscopic examination on the transport mecha- nism with bovine serum albumin. J Inorg Biochem 135:86-99 (2014).

47 Almeida MMB, de Sousa PHM, Arriaga AMC, do Prado GM, Magal- hães CEdC, Maia GA, et al., Bioactive compounds and antioxidant activity of fresh exotic fruits from northeastern Brazil. Food Res Int 44:2155 - 2159 (2011).

48 Stratil P, Klejdus B and Kubáò V, Determination of phenolic com- pounds and their antioxidant activity in fruits and cereals. Talanta 71:1741-1751 (2007).

49 do Nascimento EMGC, Mulet A, Ascheri JLR de Carvalho CWP and Cárcel JA, Effects of high-intensity ultrasound on drying kinetics and antioxidant properties of passion fruit peel. J Food Eng 170:108 - 118 (2016). 
QUERIES TO BE ANSWERED BY AUTHOR

IMPORTANT NOTE: Please markyour corrections and answerstothese queriesdirectly ontothe proof atthe relevant place. DO NOT mark your corrections on this query sheet.

\section{Queries from the Copyeditor:}

AQ1. Please confirm that given names (red) and surnames/family names (green) have been identified correctly

AQ2. Figure 1 is poor quality, Kindly resupply.

AQ3. Please give the centrifugation rate in terms of $\times \mathrm{g}$, not $\mathrm{rpm}$.

AQ4. A running head (short title) was not supplied. Please check that the running head now provided is appropriate, and indicate any necessary alterations.

AQ5. Please give the centrifugation rate in terms of $\times \mathrm{g}$, not $\mathrm{rpm}$.

AQ6. Do you mean the same row or the same column, please?

AQ7. A running head (short title) was not supplied. Please check that the running head now provided is appropriate, and indicate any necessary alterations. 